\author{
Lyudmila Svistun, Taina Zavora, Yuliia Khudolii \\ Poltava National Technical Yuri Kondratyuk University \\ Pershotravneviy avenue, 24, Poltava, Ukraine, yul.dov@gmail.com
}

\title{
PROSPECTS FOR THE IMPLEMENTATION OF REAL ESTATE DEVELOPMENT IN UKRAINE BASED ON ENERGY EFFICIENCY PRINCIPLES AND THE PROBLEMS WITH RAISING THE FINANCE REQUIRED
}

\begin{abstract}
The main goal of the study is to analyse the residential real estate market in Ukraine from the point of view of the need and the possibility of increasing its energy efficiency. Also, it aims to justify effective financial and credit mechanisms for ensuring measures to improve the thermal protection properties of residential and nonresidential real estate, in particular by introducing energy efficiency development projects. With this research we investigated Ukraine's housing stock and utility tariffs and concluded that a beneficial strategy to be applied in Ukraine is the energy-efficient retrofit of real estate. This is one of the most effective ways to re-profile unclaimed real estate units in the existing state or to reconstruct inefficiently used buildings. Also, we reviewed selected methods of energy efficient residential real estate development and mechanisms of financing energyefficient renovation of real estate used in the EU. And, in our view, the next step of the Ukraine in the direction of improving the energy efficiency of housing should be the effective operation of a dedicated/specific energy efficiency fund to ensure stable financing of housing modernization projects, which will allow for a comprehensive renovation of buildings and lead to significant annual energy savings in this end-use sector.
\end{abstract}

\section{Key words}

thermo-modernization, housing stock, energy efficiency, financing mechanisms

\section{Introduction}

In the current economic conditions in the post-Soviet space of Ukraine, real estate development is becoming increasingly popular. We use this term to determine an activity for the implementation of investment projects in real estate for the creation or reconstruction or improvement of facilities with subsequent marketing, management, and disposal of results [4]. Often this is the reconstruction of irrationally used buildings. At the same time, modern world trends in the functioning of real estate requires determining the directions of reconstruction of the Ukrainian housing stock on the basis of increasing its energy efficiency.

Energy savings in the housing construction and housing and communal services end-use sectors can become a priority in our state. $61 \%$ of Ukraine's housing stock was built before 1970 of which $46 \%$ dates from post-war years and the first period of the introduction of industrial prefabricated apartment blocks (50-60 years), and the remaining $15 \%$ from the pre-war period. All of them require major repairs. More than $70 \%$ of the housing stock (about 105 million $\mathrm{m} 2$ ) requires thermo-modernization and a reduction of the energy consumption level, which now is about 210-240 kWh / m2 per year (on average for the housing stock as a whole), according to the estimates of the Ministry for Regional Development, Building and Housing of Ukraine [1]. Problems of shortage and a high cost of energy carriers, as well as low incomes of the population, do not allow the majority to pay utility bills, also provoke a decrease in energy consumption in the residential sector. Finally, the challenges of sustainable development, combating climate change requires urgent action on energy efficiency. Solving these issues is possible through the introduction of new energy-saving materials and technologies in the construction of new or reconstruction of obsolete buildings. Therefore, in the current conditions of rising energy costs, it is advisable to implement the development and redevelopment of the residential real estate only on the basis of energy efficiency.

Analysis of previous work by V. Barannik [2], S. F. Yermilov, V. M. Heiets, Yu. P. Yashchenko [3], R. B. Peiser, A. B. Frej [4], M. Dyba, Ye. A. Polishchuk [5] and also our own studies [6 - 10] have allowed us to identify the problems of the non-energy efficient functioning of a residential real estate in Ukraine and to suggest ways of their solution with the help of energy efficient development.

At the same time, little attention has been paid to research on mechanisms for financing development projects for the construction and reconstruction of housing on the basis of energy efficiency and energy conservation 
and justification of financing schemes [11]. In connection to this, a second aim of the study is to analyse the residential real estate market from the point of view of the need and the possibility of increasing its energy efficiency and the rationale through effective financial and credit mechanisms for ensuring measures to improve the thermal protection properties of residential and non-residential real estate, in particular by introducing energy efficiency development projects.

\section{An analysis of Ukraine's housing stock}

At the beginning of 2016, the residential housing stock of Ukraine increased by 1\% compared to 2015 and amounted to a total 973.8 million $\mathrm{m} 2$ of built surface. The share of the residential housing stock in urban settlements represented the $60.8 \%$ ( 592.5 million $\mathrm{m} 2$ ) of the total. According to the State Statistics Service, $98.2 \%$ of entire housing stock was placed in the houses of apartment type, and $1.8 \%$ - in dormitories and residential premises in non-residential buildings [13].

The distribution of the housing stock by the years of construction (Fig. 1) shows that about half of the housing stock was put into operation in the post-war years and in the first period of the introduction of prefabricated apartment buildings (in the 1945 to 1970 period). A significant part of the country's housing stock, where about $50 \%$ of the population lives, is in an obsolete or in an emergency condition and requires major repairs. According to experts from the Ministry of Regional Development, as of January 1, 2017, about $90 \%$ of the housing stock would require thermal modernization $[12,13]$. In this regard, more than 40,000 multi-storey buildings need to increase their energy efficiency and reduce the level of energy consumption through reconstruction and thermal upgrading.

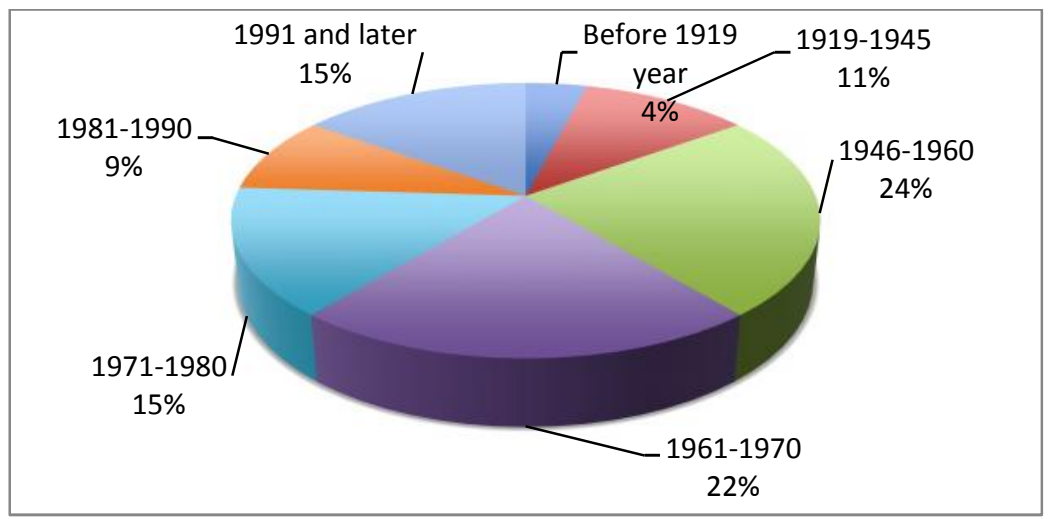

Fig. 1. Structure of the housing stock of Ukraine by years of construction Source: [13]

For example, an inventory of the housing stock in the Poltava region - typical central region of Ukraine - found that the largest share (25.67\%) the residential houses were put into operation in 1946-1960. And 22.94\% of houses constructed in 1961-1970 (Table 1). At the beginning of 2016 out of 36 million $\mathrm{m} 2$ total area of housing in the Poltava region in poor condition were 170 thousand $\mathrm{m} 2$ premises [13].

Table 1. Distribution of residential houses by the year of construction in the Poltava region, number

\begin{tabular}{|c|c|c|c|c|c|c|c|c|}
\hline & \multirow[b]{2}{*}{$\begin{array}{c}\text { All } \\
\text { houses }\end{array}$} & \multicolumn{7}{|c|}{ Including built in the period } \\
\hline & & $\begin{array}{c}\text { Before } \\
1919 \\
\text { year }\end{array}$ & $\begin{array}{c}1919- \\
1945\end{array}$ & $\begin{array}{c}1946- \\
1960\end{array}$ & $\begin{array}{c}1961- \\
1970\end{array}$ & $\begin{array}{c}1971- \\
1980\end{array}$ & $\begin{array}{c}1981- \\
1990\end{array}$ & $\begin{array}{c}1991- \\
2006\end{array}$ \\
\hline Poltava region & 423312 & 17751 & 52408 & 108668 & 97112 & 66801 & 50216 & 30356 \\
\hline Poltava (city) & 21250 & 2326 & 1982 & 3082 & 3828 & 3432 & 3156 & 3444 \\
\hline Gorishny Plavny & 2354 & 71 & 226 & 628 & 490 & 419 & 275 & 245 \\
\hline Kremenchug & 16100 & 494 & 1784 & 3828 & 3564 & 2807 & 1878 & 1745 \\
\hline Lubny & 9168 & 466 & 854 & 2093 & 2155 & 1882 & 1132 & 586 \\
\hline Mirhorod & 7680 & 206 & 513 & 1610 & 1931 & 1861 & 1030 & 529 \\
\hline
\end{tabular}

Source: $[6,13]$ 
According to experts, Ukraine would need to prioritize the thermal modernization of houses constructed in the period 1971-1980 - which is about 105.1 million m2. In a second stage, buildings from the period 1981-1990 should be modernized. This situation is similar in most regions of Ukraine [12].

Fig. 2 shows the distribution of residential and non-residential buildings of the Poltava city by year of construction. Reconstruction and thermo-modernization are primarily needed for buildings located both in the central part of the city and in other areas.

Fig. 2 shows the distribution of residential and non-residential buildings in the city of Poltava according to the year of construction. Reconstruction and thermos-modernization is needed for buildings located both in the central part of the city, and in the more remote areas.

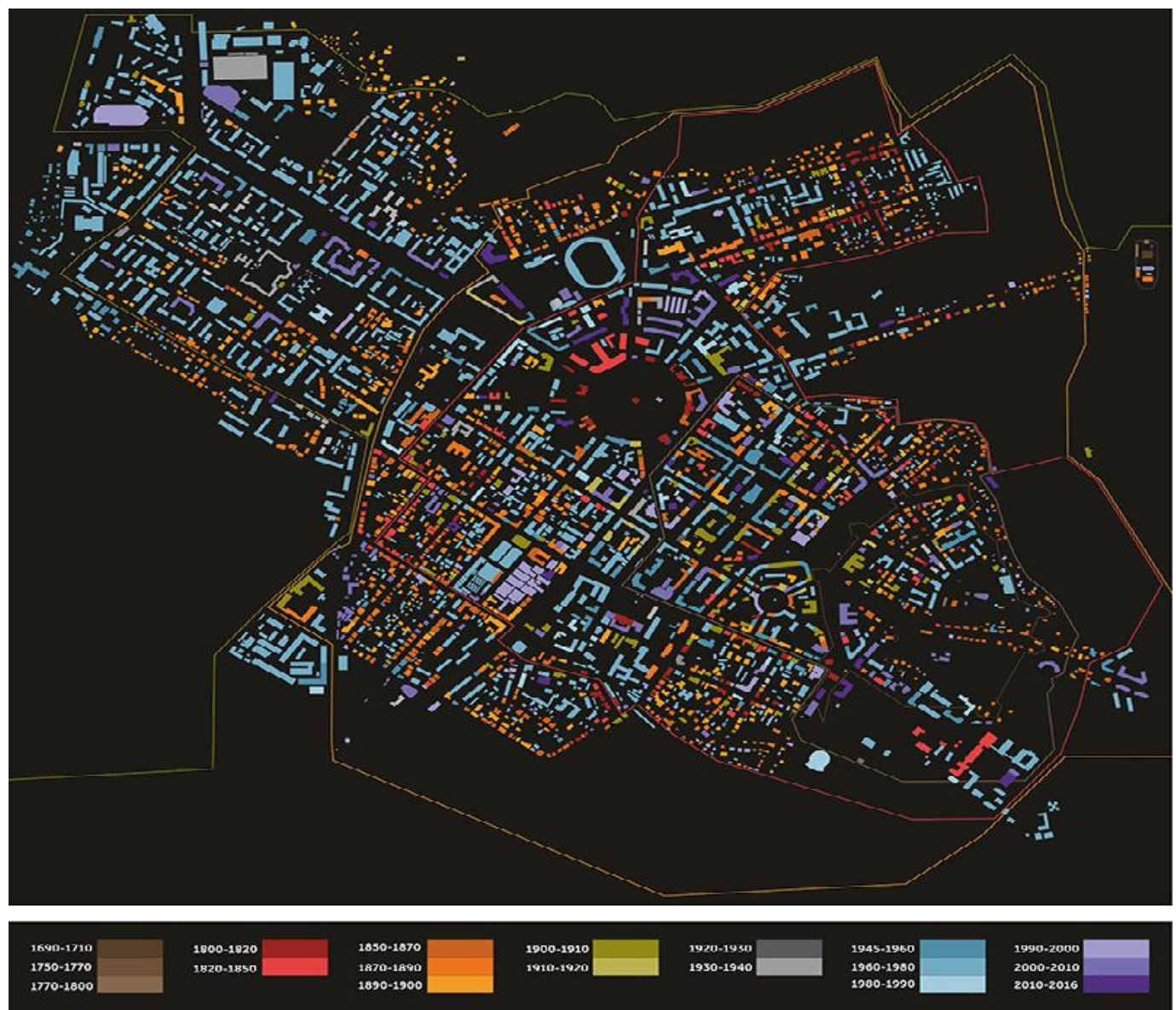

Fig.2. Territorial location of buildings and structures by the years of construction in the city of Poltava Source: according to the information of City-Lab

The acute crisis of the entire economic system of Ukraine in 2014-2016 coinciding with the military intervention of Russia in Ukraine led to a reduction in the size of the construction industry at a rate faster than most other sectors (Fig. 3). That is, the construction of housing under the new energy efficiency standards is now practically impossible as the cost of such housing is too high, which makes it impossible to satisfy the needs of Ukrainians in high-quality, economical housing. 


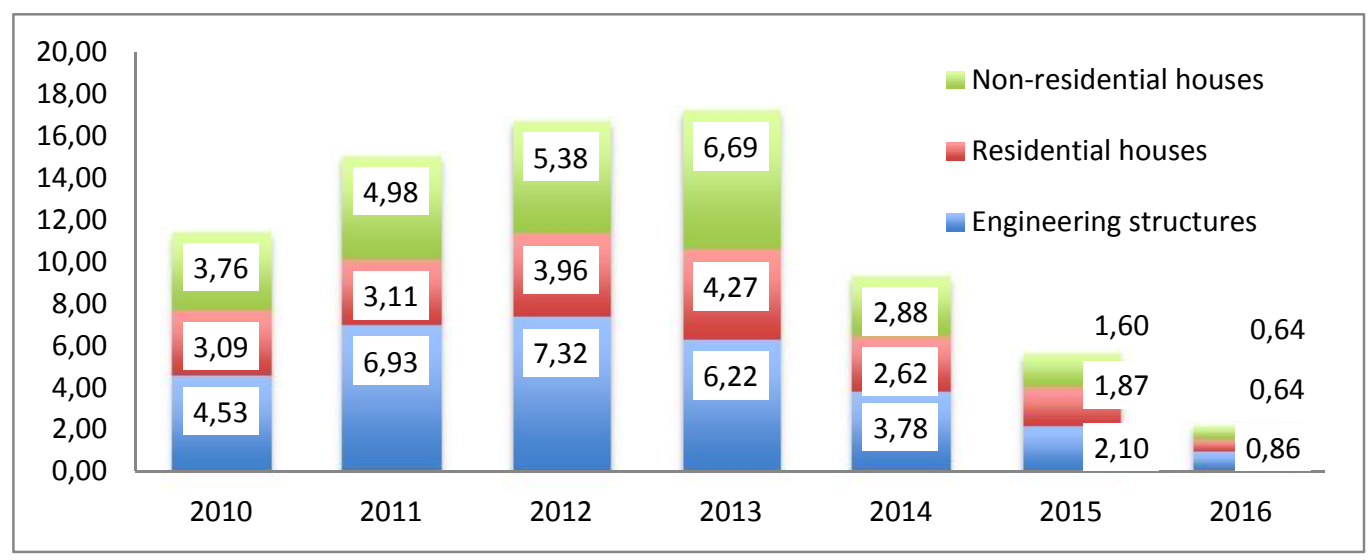

Fig. 3. Dynamics of the volume of completed construction work in 2010-2016, billion US dollars Source: [14]

At the same time, a huge problem for the population of Ukraine is the constant increase in tariffs for utilities. Over the past 2.5 years the tariffs for district heating all over Ukraine grew up 5.5-10 times and for hot water 4.8 times (Fig. 4), while average wages increased by only $110 \%$ in $2008-2015$, and by $37 \%$ in $2016-2017-$ [15]. Limiting the household's energy consumption in this situation can only be considered as a temporary approach on the way to solving the energy saving problem.

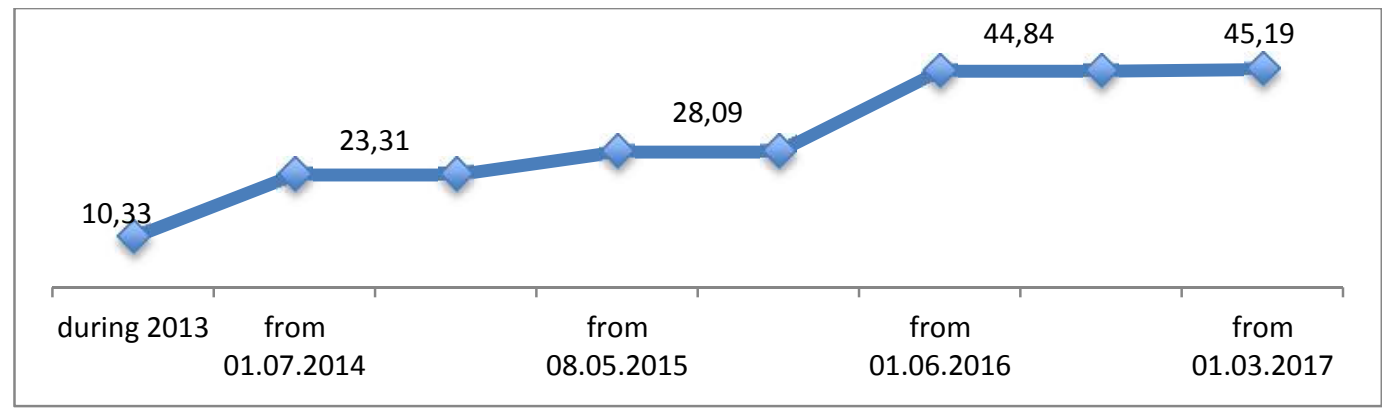

Fig. 4. Dynamics of the tariffs for "Kyivenergo" for heating with the use of meters, EUR/Gcal Source: [16]

Since July 1, 2016, tariffs for heating and hot water for households have more than doubled. The average heat tariff for households in 2015 was $534 \mathrm{UAH} / \mathrm{Gcal}$ (21.4 EUR/Gcal), the weighted average tariff (according to The Ministry for Regional Development, Building, and Housing of Ukraine calculations), is set at $1303.36 \mathrm{UAH} / \mathrm{Gcal}$ (47.4 EUR/Gcal) from July 1, 2016 (Fig. 5) [1]. This is due to the establishment of a single gas price for households and businesses for heat and power utilities from 2.9 to 6.9 thousand UAH per thousand cubic meters.

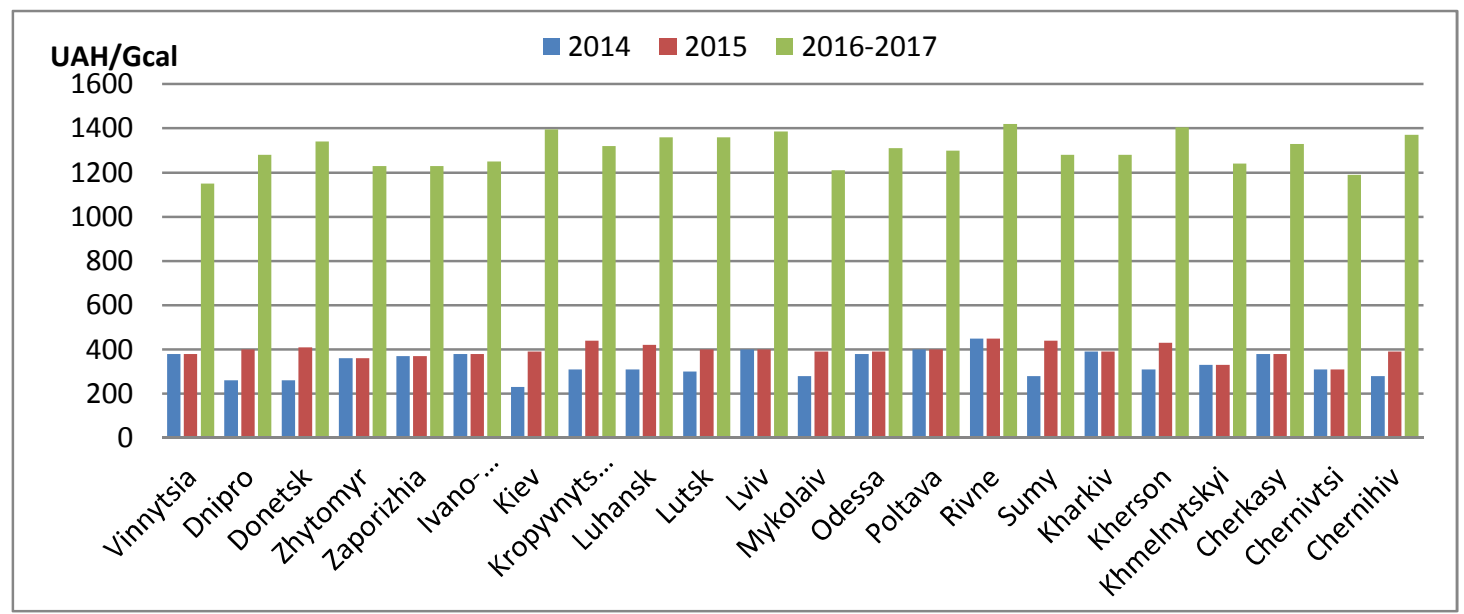

Fig. 5. Dynamics of tariffs for residents of apartment houses with house and apartment heat meters Source: $[13,16]$ 
The level of domestic energy consumption for heating in Ukraine remains at the level of the building technical standards of the $80 \mathrm{~s}$ (an average of $210-240 \mathrm{kWh} / \mathrm{sqm}$ per year). This figure is much higher than the European countries (about $125 \mathrm{kWh} / \mathrm{sqm}$ per year) [35].

Developed countries of the world and, first of all, the EU countries, have already achieved success to some extent in solving the problems of energy efficiency of buildings, ensuring the reduction of housing energy needs in heat and electric energy, continue to search for new sources of energy supply and development of energy saving measures. For example, by 2021, European countries plan to completely switch to nearly zeroenergy buildings (NZEBs) and positive energy buildings that generate more energy than what they consume $[18,29,30]$. Such houses produce enough renewable energy to meet its own annual energy consumption requirements. The house is heated usually using alternative renewable energy sources (solar collectors, heat pumps, wind generators, etc.), and also taking into account the heat released by people who live in it, by household appliances, etc. At the same time, heat losses are prevented due to the design features of the building, for the construction of which modern energy-saving technologies and highly effective thermal insulation materials are used (Table 2).

Table 2. Consumption of thermal energy depending on the type of buildings the example of Germany

\begin{tabular}{|c|c|c|}
\hline House area $140 \mathrm{~m}$ & $\begin{array}{l}\text { Annual energy consumption, } \\
\mathrm{kWh} /\left(\mathrm{m}^{2} \mathrm{a}\right)\end{array}$ & Specific heat loss, Wh /(m2) \\
\hline Old building & 300 & 136 \\
\hline Typical house of the 1970's. & 200 & 91 \\
\hline Typical house of the 1980's. & 150 & 68 \\
\hline $\begin{array}{l}\text { Low energy consumption house of the } \\
1990 \text { 's. }\end{array}$ & 70 & $14-32$ \\
\hline House of ultra-low power consumption & $15-30$ & $7-14$ \\
\hline Modern Passive House & Less than 15 & Less than 7 \\
\hline
\end{tabular}

Source: [19]

Simplified energy-efficient home technology includes four main aspects: the thermal insulation of walls and roofing, the sealing of windows and doors, energy-efficient ventilation and the substitution of inefficient boilers. In general, these interventions allow reducing heat consumption and improving the financial value of housing. Also, measures for power management, automatic control, hydraulic balancing of the heating system, and thermostatic valves on the radiators contribute to energy efficiency. Reducing energy consumption also reduces environmental pollution from non-renewable sources of energy (natural gas, fuel oil, coal), which creates a positive effect on the environment both locally and globally.

The investment costs for a newly built energy efficient house are 10-20\% higher than traditional one, mainly due to the costs of additional insulation and ventilation, but operating costs are $60-70 \%$ lower [20]. Given the Ukrainian energy costs, a $140 \mathrm{~m} 2$ home heated with natural gas, the potential annual savings of implementing these measures will amount to USD 1800, and to USD 1500 in the case of houses with electric heating [21].

According to the standards of state building codes of Ukraine V.2.6.-31: 2006 "Building. Structures for buildings and constructions. Thermal insulation of buildings" by 2014 [17] government already created an energy classification of buildings and developed the formula calculation of unit costs, but regulatory requirements are focused primarily on limiting consumption of heat for heating of buildings and require bringing to the European standards of comfortable living and the construction of passive houses.

Currently, the construction industry also created a legal and methodological framework for energy efficiency in the design and construction of housing for civil purposes, which provides energy savings of over $30 \%$ in buildings, compared to the corresponding rules in force until 1994 [21 - 23]. However, these regulatory requirements are mandatory only in the design and construction of new residential and public buildings and structures [31]. This constrains the reconstruction of existing facilities according to the European energy efficiency requirements. However, in the EU energy efficiency reconstruction is generally accepted and is supported in every way at the state and local levels. 
In nowadays Ukraine where district heat tariffs grow and there are increasing problems with the operation of obsolete buildings, an urgent retrofitting of the country's old housing stock is required. One of the best ways that can be used in Ukraine is an energy-efficient development or redevelopment of real estate. This is one of the most effective ways to re-profile (reassign) unclaimed real estate units in the existing state or to reconstruct inefficiently used buildings. It benefits not only the developers but also the city, as it provides for the modernization of real estate, the improvement of the urban environment, the quality of life.

The financing and implementation of real estate development in Ukraine

Table 3 presents the proposed method of energy-efficient residential real estate development in Ukraine.

Table 3. Methods of energy efficient residential real estate development used in the world practice

\begin{tabular}{|c|c|}
\hline Principles & Methods \\
\hline \multirow{6}{*}{$\begin{array}{l}\text { Methods based on the } \\
\text { principle of autonomy }\end{array}$} & Use of renewable energy sources (solar collectors, solar panels, heat pumps) \\
\hline & Use of rainwater, recycling water \\
\hline & Light sensors \\
\hline & Efficient window constructions \\
\hline & Green roof \\
\hline & Thermal zoning of houses and apartments \\
\hline \multirow{6}{*}{$\begin{array}{l}\text { Methods based on the } \\
\text { principle of } \\
\text { architectural efficiency }\end{array}$} & Bulk shape selection \\
\hline & Reducing the ruggedness of external walls \\
\hline & Increase the width of the section body \\
\hline & Creating houses of the corridor type \\
\hline & Compact house \\
\hline & Maximum directionality to the south \\
\hline \multirow{4}{*}{$\begin{array}{l}\text { Methods based on the } \\
\text { principle of } \\
\text { environmental } \\
\text { friendliness }\end{array}$} & Greening facades \\
\hline & Greening of roofs \\
\hline & Landscaping of local areas \\
\hline & Reducing traditional energy sources \\
\hline \multirow{4}{*}{$\begin{array}{l}\text { Methods based on the } \\
\text { principle of socio- } \\
\text { economic expediency }\end{array}$} & Increase in the number of apartments per staircase-elevator unit \\
\hline & Compliance with the requirements for the area of apartments \\
\hline & Application of different types of sections \\
\hline & Application of different types of apartments \\
\hline
\end{tabular}

Source: [11]

The approval of the law on the complex reconstruction of quarters (micro-districts) through an obsolete housing fund should also contribute to positive moves in the direction of the retrofitting of the housing stock.

Energy-saving development projects require significant capital investment. Energy efficiency projects can be financed using different mechanisms and sources of financing. The economic mechanism for introducing energy-saving technologies in construction and retrofitting of housing should include tax exemptions for investors, accelerated depreciation of energy-saving equipment, financial support for leasing energy-efficient equipment, soft loans.

The current legislation provides the following sources of capital for financing energy-efficient renovation of real estate:

- Financial resources of investors participating in the implementation of reconstruction projects, replacement of housing stock;

- Financial resources from reconstruction funds, replacement of housing stock;

- Financial resources in the form of regional, district, district budgets in cities and local government budgets $[22,25]$. 
However, in the context of the post-2014 economic crisis and the lack of budgetary resources for capital expenditures and for maintaining programs at both the state and local levels, as well as problems in the banking sector, the funds of international financial organizations and private investors can serve as alternative or complementary sources of financing for residential real estate retrofitting projects.

The main international financial institutions, organizations and funds that finance and finance energy saving projects in Ukraine include: the World Bank (WB), the European Bank for Reconstruction and Development (EBRD), the International Finance Corporation (IFC), the Nordic Environment Finance Corporation (NEFCO), The Eastern Europe Energy Efficiency and Environment Partnership (E5P), the United States Agency for International Development (USAID), the German Society for International Cooperation (GIZ), The Swedish International Development and Cooperation Agency (SIDA).

Table 4. The programmes of international donor organizations to support energy-efficient projects in real estate in Ukraine

\begin{tabular}{|c|c|c|}
\hline Donor & Name & Features \\
\hline $\begin{array}{l}\text { The } \\
\text { International } \\
\text { Finance } \\
\text { Corporation } \\
\text { (IFC) }\end{array}$ & $\begin{array}{l}\text { "Energy } \\
\text { efficiency in the } \\
\text { residential } \\
\text { sector of } \\
\text { Ukraine" }\end{array}$ & $\begin{array}{l}\text { Formation of the regulatory framework, which would allow homeowner } \\
\text { associations (HOAs) and apartment buildings management companies to receive } \\
\text { funding to improve the energy efficiency of apartment buildings. Cooperation } \\
\text { with Ukrainian banks in developing and promoting market viable loan products } \\
\text { designed for HOAs and apartment buildings management companies. }\end{array}$ \\
\hline \multirow{3}{*}{$\begin{array}{l}\text { The German } \\
\text { Society for } \\
\text { International } \\
\text { Cooperation } \\
\quad \text { (GIZ) }\end{array}$} & $\begin{array}{l}\text { "Energy } \\
\text { Efficiency in } \\
\text { Buildings" }\end{array}$ & $\begin{array}{l}\text { The project provided assistance to four Ukrainian cities on energy audit, business } \\
\text { planning and energy monitoring system and training. The project supported the } \\
\text { development of business plans for the NEFCO Energy Savings Programme in } \\
\text { Chernihiv, Ivano-Frankivsk, Mirgorod and Novohrad-Volynsky. }\end{array}$ \\
\hline & $\begin{array}{l}\text { "Energy- } \\
\text { efficient } \\
\text { buildings" }\end{array}$ & $\begin{array}{l}\text { On the basis of a new complex of residential and office buildings in Kyiv, energy- } \\
\text { saving construction concepts are being implemented using modern, } \\
\text { environmentally friendly technologies. The results of this pilot project are } \\
\text { distributed through the Ukrainian construction sector. }\end{array}$ \\
\hline & $\begin{array}{l}\text { "Energy } \\
\text { Efficiency in } \\
\text { Communities" }\end{array}$ & $\begin{array}{l}\text { Supporting the ability of local self-government to play the leading role in Ukraine } \\
\text { in implementing energy-efficiency measures. Including facilitating access to funds } \\
\text { and credit lines for financing such activities. Within the framework of the GIZ } \\
\text { project and the Ministry of Regional Development, five consortia of cities were } \\
\text { selected for participation. The leader of the consortium of cities is the Poltava } \\
\text { Regional State Administration. }\end{array}$ \\
\hline $\begin{array}{l}\text { The German } \\
\text { Development } \\
\text { Bank (KfW) }\end{array}$ & $\begin{array}{l}\text { Cooperation } \\
\text { with ProCredit } \\
\text { Bank }\end{array}$ & $\begin{array}{l}\text { Financial and technical assistance to ProCredit Bank in providing loans to small, } \\
\text { medium and large businesses and households to improve energy efficiency. The } \\
\text { credit line is } 35 \text { million euros, with a maturity of } 7 \text { years. }\end{array}$ \\
\hline
\end{tabular}

Source: $[26,27]$

However, the funds allocated for these pilot programs are not enough to address the energy inefficiency of Ukraine's housing stock. In connection to this, there is an urgent need to search for new models and schemes for financing projects for the reconstruction and improvement of buildings' energy efficiency, including the implementation the world practice of using tools applied in other countries.

One of these alternatives financing mechanisms are revolving funds, i.e., a fund set up for specified purposes with the provision that repayments will be used again for the purposes of the fund [28]. Continual reinvestment in projects with little payback period accumulates new resources at the expense of cash flows that come into the fund. The revolving fund model is an effective financial mechanism in cases of budgetary shortages in local and regional administrations. Because the energy efficiency revolving funds usually offer loans on more loyal terms than banks. The repayment of such loans is achieved through energy savings and the returned loans are used to finance new energy efficiency projects. In fact, the revolving fund - a special bank account, opened by a non-governmental organization (NGO). Also, the transactions of such an organization are not taxed.

A proposal of indicative financial conditions for a revolving fund can be:

- Loans from 15.000 to 500,000 euros, which can be given to private single-family house owners, groups of the owners of individual apartments, who cooperate with each other on the basis of a certain 
contract, or homeowner associations/HOAs (provided that the legislation will have clear mechanisms for paying the HOAs o its obligations);

- The borrower's contribution to investment is at least $10 \%$ of total amount;

- A grace period of 2 years with a 10 -year return period;

- A grant of $20-35 \%$ of total investment costs of housing retrofit is issued;

- $10 \%$ annual interest rate that may be subject to discussion in accordance with the risk assessment of a particular project;

- Management fee (3\%);

- The cost of technical assistance [11].

Another type of models used in other countries that could potentially be tested in Ukraine is the ESCO model. Energy Performance Contracting (EPC) is a kind of project-financing mechanism involving third-party investments, where the main goal of the implementation is to increase energy efficiency or reduce energy consumption. Usually, the executors of EPC projects are professional energy service companies (ESCOs) [7].

The ESCO model is one of the solutions that have proved its effectiveness in working with consumers (in many European markets). However, it should be noted that ESCOs are mainly used in public sector projects, whereas this model is not very common private housing in Europe. In some countries, such as Sweden, Estonia, and Lithuania, ESCO models have been commercially successful in the residential sector (according to the ECEEE Report "Latest developments of the ESCO industry across Europe", 2017) [33]. The ESCO is usually considered a good model for implementing energy efficiency projects.

ESCO models were introduced for the financing of energy efficiency in Ukraine at the beginning of 2000. However, this business is developing more in the industrial sector or in the sphere of small and medium-sized enterprises, while the demand for these services hasn't appeared yet in the residential sector [11]. Also since 2016, ESCOs have been implementing projects to improve the energy efficiency of public buildings. In 2016, 27 tenders were announced, and after successful completion of tender procedures, another 38 ESCOs were signed for the amount of more than UAH 40 million. In 2018 it is expected to conclude more than 250 energy service agreements [32].

Finally, a classic instrument for financing projects for the reconstruction and improvement of energy efficiency of housing are special preferential loan programs offered by banks with the support of the government or local authorities. A striking example of the support and encouragement of the population to the reconstruction of the housing stock in Germany is a special credit program of the German Development Bank (KfW), $80 \%$ of which belongs to the federal government and $20 \%$ to the federal lander. The bank offers 3 credit programs: "Energy-Efficient. Building. Refurbishment (151/152)" amounting to 100,000 € for a period of up to 30 years at $1.62 \%$ per annum with a grace period of one year return; "Renewable energy sources (167)" amounting to $50,000 €$, for a period of 2 to 20 years at $1.05 \%$ per annum and "Energy efficient repair (additional credit)" conditions, are individually discussed $[27,33]$.

\section{Summary and conclusions}

The current state of the housing stock in Ukraine requires the early resolution of the problem of increasing energy efficiency in the residential sector, as well as the energy and economic situation in the country. In general, the experience of developed countries indicates the need for state regulation of energy saving processes in the field of real estate and conduct a well-defined policy, as they are on the one hand strategically important, but on the other require significant financial resources available. Only the state can ensure the efficiency of financial mechanisms to improve the energy efficiency of real estate operation through a balanced legislation, flexible price, financial, tariff and tax policies.

Recent years have seen growing attention by state, owners, and developers to the energy efficiency of buildings, and, accordingly, the use of modern technologies to significantly reduce energy consumption in the residential sector, as well as improve living conditions and reduce the residents' funds to pay for housing and communal services. In view of rapidly rising in energy prices (in particular, natural gas), the important measures should be taken by the state to stimulate energy saving in the housing stock and introduce mechanisms for the financial provision of such measures. 
Simple and effective lending models for energy efficiency measures that are applicable in world practice can prove their effectiveness in Ukraine. Given the current financial and economic situation and the existing legislation, it is necessary to develop first of all a bank lending model for thermo-modernization and a model of a revolving fund for energy efficiency. The model of ESCO financing is still rather difficult to use in housing stock of Ukraine.

Bank lending is to be financed by credit programs from European banks (for example, from the EBRD), as well as loans guaranteed by the government of Ukraine. This will allow granting subsidies for the capital reconstruction of the housing stock, but it requires considerable state subsidiarity support.

Another potentially attractive and efficient model is the creation in Ukraine of a revolving fund for energy efficiency. Typically, such funds provide soft loans. The fund can be created with the participation of European banks, the government of Ukraine, the National Bank of Ukraine, other donors. This model quite simply and effectively allows consolidating the funds of the state and other donor organizations interested in supporting energy efficiency in the housing sector. With the help of such funds, reinvestment in new energy-saving projects takes place, which increases the efficiency in the use of public funds. At the same time, this encourages local banks to enter the market for investments in energy efficiency in the residential sector. However, due care must be taken to ensure that such a fund enables effective control over the distribution and expenditure of funds, and generally operates in a transparent, public manner.

\section{References}

[1] The Ministry for Regional Development, Building and Housing of Ukraine, official website, http://www.minregion.gov.ua.

[2] V. Barannik, Energy efficiency in the state as an indicator of competitiveness. Interstate comparison, Economic bulletin of NTUU „KPI” (2010), http://economy.kpi.ua/files/files/3_kpi_2010_7.pdf.

[3] S. F. Yermilov, V. M. Heiets, Yu. P. Yashchenko, Energy Efficiency as a Resource of Innovative Development: National Report on the Status and Perspectives of Implementing the State Energy Efficiency Policy in 2008, NAER, Kyiv, 2009.

[4] R. B. Peiser, A. B. Frej, Professional Real Estate Development: The ULI Guide to the Business Second Edition, ULI-the Urban Land Institute, Washington, D.C., 2003.

[5] M. Dyba, Ye.A. Polishchuk, Developerski kompanii na investytsi-inomu rynku Ukrainy, KNEU, Kiyiv, 2011.

[6] T. Zavora, Energy efficiency of housing in the context of ensuring the energy security of the state, Economic aspects of energy conservation: problems and ways of their solution: collective monograph, V. Chevganova (Eds.), PoltNTU, Poltava, 2015, pp. $145-151$.

[7] L. Svistun, Prospects for the development of ESCO financing of energy efficiency projects in Ukraine, Problems of Formation and Development of Innovative Infrastructure: European Vector - New Challenges and Opportunities, Abstracts at the III International Scientific and Practical Conference, Lviv Polytechnic, Lviv, 2015, pp. 302-303.

[8] L. Svystun, Y. Khudolii, T. Zavora, Directions of energy efficiency in the construction sector in view of the foreign experience, Energy efficiency of the economy: problems of today and tomorrow: International scientific-practical conference, PoltNTU, Poltava, 12 - 13 October 2016, pp. $66-71$.

[9] Y. Khudolii, T. Zavora, L. Svistun, Preconditions for the introduction of thermo-modernization measures of the housing fund in Ukraine, Abstracts at the 15th International Scientific Conference Information Technologies and Management 2017, Riga, Latvia, 27 - 28 April, 2017, pp. 138 - 139.

[10] T. Zavora, L. Svystun Y. Khudolii, Conceptual bases of formation of a housing policy based on energy efficiency and energy conservation, Energy efficiency of the economy: problems of the present and future: collective monograph, PoltNTU, Poltava, 2017. pp. 46-62. 
[11] Thermo modernization of housing stock: organizational, legal, social, financial and technical aspects: practical issue, third ed., V. Bryhilevych (Eds.), Lviv, 2016, http://www.cdms.org.ua/Files/TermModH.pdf.

[12] In Ukraine, about 90\% of high-rise buildings require thermo modernisation (2016), http://www.nova.poltava.ua/v-ukraïni-blizko-90-bagatopoverxivok-potrebuyut-termomodernizaciï/.

[13] Residential fund of Ukraine, http://ukrstat.org/uk/operativ/menu/menu_u/if.htm.

[14] Development of the construction industry 2010-2016, Ukrainian Center of Steel Construction (2016).

[15] The purchasing power of the Ukrainian is falling more and more, http://publicaudit.com.ua/news/kupivelna-spromozhnist-ukrayintsiv-vse-bilshe-padaye.

[16] Changes in tariffs for heat energy for households, National energy and utilities regulatory commission, official

website, http://www.nerc.gov.ua/data/filearch/teplo/dynamika_taryfy/naselennia/Dynam_taryfy_teplo_naselennia.pdf

[17] State building codes of Ukraine V.2.6.-31: 2006 "Building. Structures for buildings and constructions. Thermal insulation of buildings", http://dbn.at.ua/load/normativy/dbn/1-1-0-13.

[18] A Common Definition for Zero Energy Buildings" (2015), US Department of Energy, https://www.energy.gov/sites/prod/files/2015/09/f26/A\%20Common\%20Definition\%20for\%20Zero\%20Energy \%20Buildings.pdf.

[19] Energy Efficiency Standards in Europe and Germany, ESCO. Energy service, Volume 8, 2013, http://www.journal.esco.co.ua/esco/2013_8/art32.html.

[20] Passive house for the price of a two-bedroom apartment (2017), http://akvilonpro.ua/ru/docs/passivehouse/Pasivniy-dom-po-tsene-trehkomnatnoy-kvartity.html.

[21] N.O. Kondratenko, I.S. Balandina, Aspects of the problem of rationing energy consumption in housing construction, Municipal economy of cities, Volume 87, 2009, pp. 70-76.

[22] About the Concept of State Housing Policy: Verkhovna Rada of Ukraine Resolution № 254/95-BP from 30.06.1995, Information from the Verkhovna Rada of Ukraine, Volume 7, 1995, pp. 200.

[23] Draft Law of Ukraine "On the energy efficiency of residential and public buildings", http://w1.c1.rada.gov.ua/pls/zweb2/webproc4_1?pf3511=53059.

[24] N. V. Mytsa, Essence and problems of energy saving in Ukraine, Sustainable development of economy, Volume 4, 2011, pp. 40-47.

[25] V. Onishchenko, T. Zavora, Organizational and economic aspects of modern housing policy: a regional dimension, Poltava, PoltNTU, 2011.

[26] L. Svistun, Y. Dovgal, Mortgage lending in Ukraine: current problems and development factors, PoltNTU, Poltava, 2014.

[27] Energieeffizient Sanieren - Kredit, https://www.kfw.de/inlandsfoerderung/Privatpersonen/ Bestandsimmobilien/Finanzierungsangebote/Energieeffizient-Sanieren-Kredit-(151-152).

[28] „Revolving Fund” Merriam-Webster.com. (2018), https://www.merriam-webster.com/dictionary/revolving fund.

[29] Nearly zero-energy buildings, European Commission, https://ec.europa.eu/energy/en/topics/energyefficiency/buildings/nearly-zero-energy-buildings. 
[30] EPBD Directive 2010/31/EU on the energy performance of buildings, http://www.rehva.eu/en/epbd.

[31] New energy strategy of Ukraine until 2020: security, energy efficiency, competition, http://old.razumkov.org.ua/upload/Draft\%20Strategy_00\%20(7).pdf.

[32] State Agency for Energy Efficiency and Energy Conservation of Ukraine, http://saee.gov.ua/uk/content/energoservis_1.

[33] Real Estate Financing. (2015). Wealth Opportunities in Commercial Real Estate, pp. 119-155, DOI: 10.1002/9781119202790.ch5.

[34] Latest developments of the ESCO industry across Europe (2017), https://www.eceee.org/library/conference_proceedings/eceee_Summer_Studies/2017/.

[35] Household energy consumption for space heating per m2 (2015), https://www.eea.europa.eu/data-andmaps/daviz/unit-consumption-of-space-heating\#tab-chart_1. 